\title{
Residual effects of neem Azadirachta indica A. Juss. (Sapindales: Meliaceae) seed-based fertilizer and NPK on the performance of Basella alba $L$. (Caryophyllales: Basellaceae) plant
}

\author{
S. A. Adejoro, D. N. Arije and A. C. Adegaye
}

Department of Crop, Soil and Pest Management, the Federal University of Technology, P.M.B 704, Akure, Ondo State. Email: dotunarije@gmail.com.

\begin{abstract}
Organomineral formulations are low input technology fertilizers, which combine the attributes of both organic and inorganic fertilizers. A completely randomized design (CRD) pot experiment was conducted in the screen house of the Department of Crop, Soil and Pest Management, of the Federal University of Technology, Akure, to evaluate the residual effects of neem Azadirachta indica A. Juss. (Sapindales: Meliaceae) seed based fertilizer and NPK 20:10:10 on the growth, yield and nutritional quality of Basella alba L. (Caryophyllales: Basellaceae). Results showed that the plots previously treated with neem seed-based fertilizer especially at $150-300 \mathrm{~kg} / \mathrm{ha}$ enhanced the growth, yield and nutritional quality of $B$. alba, and increased these parameter significantly $(\mathrm{P}<0.05)$ compared to the NPK treated and the untreated soil samples. It was therefore concluded that the Neem seed based fertilizer can serve as a viable alternative to NPK chemical fertilizers especially in rotational cropping systems owing to its prolonged soil action.
\end{abstract}

Keywords: Neem seed-based fertilizer; Organomineral; Basella alba; Efo amunututu; Soil nutrients.

\section{Introduction}

Organomineral fertilizers in recent times have caught the interests of farmers and researchers in the SubSahara Africa, and the attraction towards these formulations arose from certain
Received

February 28, 2019

Accepted

April 13, 2019

Released

April 30, 2019

Full Text Article

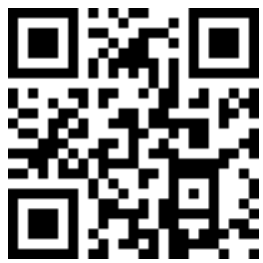

\footnotetext{
ORCID

(D) 0000-0001-9757-7903

S. A. Adejoro

D 0000-0003-2605-2741

D. N. Arije

(D) 0000-0003-3198-6653

A. C. Adegaye
} 
1993). The use of inorganic fertilizers has also been reported to be characterized with apparent inability to substantially redress the chemical and physical deterioration of the soil (Adeniyan and Ojeniyi, 2005), and may be accompanied by a decline in soil organic matter content, increased soil acidity, degradation of soil physical properties and increased rate of erosion due to instability of soil aggregates (Adeoluwa and Adeogun, 2010). These are in addition to the high cost and scarcity characterizing use of inorganic fertilizers. The huge amount of organic fertilizers required to adequately support crop production, as well as the difficulty in handling manures are some of the problems of organic sources of nutrients (Makinde et al., 2010).

John et al. (2004) have advocated an integral use of organic manure and chemical fertilizers for the supply of adequate quantities of plant nutrient required to sustain maximum crop productivity and profitability while minimizing environmental impact from nutrient use. An organomineral fertilizer is a low input technology of improving the nutrient status of tropical soils for sustainable crop production. The formulation combines the attributes of both organic and inorganic fertilizers (Ayeni, 2008), possessing the dual attributes of quick and sustained nutrient release, which will benefit optimum growth and yield in crop as well as furnish soil organisms with nutrients to derive energy for their metabolic activities. Studies with maize, pepper and amaranth as test crops revealed that these crops responded favourably to the application of organomineral fertilizers (Fagbola and Ogundipe, 2007; Adeoye et al., 2008; Ojeniyi et al., 2009; Makinde et al., 2010).

The ability of a nutrient source to provide season-long nutrient release to crops, as well as leave residues in the soil to sustain another crop in rotation will go a long way to save cost of crop production. Organomineral formulations are likely to exhibit such a cost effective attribute.

The present study seeks to gain an insight into the effects of neem Azadirachta indica A. Juss. (Sapindales: Meliaceae) seed-based fertilizer (an organomineral formulation) residues on the growth and yield performances of Basella alba L. (Caryophyllales: Basellaceae) grown as a follow-up crop in rotation where fertilizer was originally applied to maize.

\section{Materials and materials}

A screen house experiment was conducted in the screen house of the Department of Crop, Soil and Pest Management, of the Federal University of Technology, Akure, Nigeria, in 2011. Soil samples from a preliminary field experiment where neem seed-base fertilizer (an organomineral formulation) at $0(\mathrm{NF}), 100$ (N100), 150 (N150) and 200 (N200) kg/ha with NPK at 200 $\mathrm{kg} / \mathrm{ha}$ were collected into pots and transferred to the screenhouse. The experimental design was a complete randomized design (CRD) with three replications per treatment.

5 seeds of Basella alba were sown into each pot but were later thinned to one stand per pot after germination. Watering was done at two days interval, no fertilizer was applied, and emerged weeds were hand-pulled from the pots.

Growth parameters such as plant height and number of leaves per plant were taken on weekly basis beginning from the 3rd week up to the 10th weeks after planting (WAP). Plant height was measured using a tape in centimeters. Leaf number was determined by counting the total number of leaves of one plant stands in each pot, germination count and stem girth were also determined and recorded. At harvest, yield parameters as well as leaf area were determined. Leaf proximate, nutrient analysis and vitamin $\mathrm{C}$ was also carried out at Basella alba harvest. 
Leaf samples collected per pot were oven-dried at $90{ }^{\circ} \mathrm{C}$ for $24 \mathrm{~h}$, milled and ashed for $6 \mathrm{~h}$ at $500{ }^{\circ} \mathrm{C}$. Nutrients were extracted using nitric perchloric acid mixture (Tel, 1984) and $\mathrm{N}$ was determined by microkjeldahl approach. The $\mathrm{P}$ in extract was determined using molybdenum blue colorimetry and read on spectrophotometer. The $\mathrm{K}$ was determined on flame photometer, and $\mathrm{Ca}$ and $\mathrm{Mg}$ by EDTA titration. Vitamin $\mathrm{C}$ was determined using ascorbic acid as the reference compound. $200 \mathrm{~mL}$ of the extract was pipette and mixed with 300 $\mathrm{mL}$ of $13.3 \%$ of TCA and $75 \mu \mathrm{L}$ of DNPH. The mixture was incubated at $37{ }^{\circ} \mathrm{C}$ for 3 $\mathrm{h}$ and $500 \mathrm{~mL}$ of $\mathrm{H}_{2} \mathrm{SO}_{4}$ was added and the absorbance was read at $520 \mathrm{~nm}$. Leaf proximate composition including the moisture content, protein, fat, ash, carbohydrate, and crude fiber were determined according to standard methods (AOAC, 1995).
Statistical analysis was performed using analysis of variance, and means separated using Fischer's least significance test at $5 \%$ level of probability.

\section{Results and discussions}

The nutrient composition of the neem seed-based fertilizer (NSBF) used in this study is presented in Table 1 , while some soil properties of the experimental site are shown in Table 2. The soil is low in organic matter, total $\mathrm{N}$ and available $\mathrm{P}$, adequate in exchangeable $\mathrm{K}$ and $\mathrm{Ca}$, and slightly acidic. The NSBF had relatively low content of basic nutrients but a huge organic base. The critical levels of organic matter for crop production in Nigeria ecological zones is $3.0 \%$, and the value of exchangeable $\mathrm{Ca}$ was 2.2 $\mathrm{cmol} / \mathrm{kg}$ (Akinrinade and Obigbesan, 2000).

Table 1. Chemical analysis of neem seed-based fertilizer.

\begin{tabular}{lc}
\hline Parameters (\%) & Results (\%) \\
\hline Organic carbon (OC) & 37.4 \\
Nitrogen (N) & 7.0 \\
Phosphorus (P) & 7.0 \\
Potacium (K) & 7.0 \\
Calcium (Ca) & 6.2 \\
Magnessium (Mg) & 1.5 \\
\hline
\end{tabular}

Source: Royal Fertilizer Plus.

Table 2. Pre-treatment soil analysis at the site of the experiment.

\begin{tabular}{lc}
\hline Parameters & Results $\mathbf{( g ~ k g - 1})$ \\
\hline $\mathrm{pH}\left(\mathrm{H}_{2} \mathrm{O}\right)$ & 6.02 \\
Organic Carbon (\%) & 1.0 \\
Total N (\%) & 0.22 \\
Available P $\left(\mathrm{mg} \mathrm{kg}^{-1}\right)$ & 6.65 \\
Available K $\left(\mathrm{cmol} \mathrm{kg}^{-1}\right)$ & 0.30 \\
$\mathrm{Mg}\left(\mathrm{cmol} \mathrm{kg}^{-1}\right)$ & 0.65 \\
$\mathrm{Ca}(\mathrm{cmol} \mathrm{kg}-1)$ & 1.7 \\
\hline
\end{tabular}


All the rates of neem seed-based and NPK fertilizer left residues in soil, which increased vine lengths and leaf numbers of Basella alba relative to the control. However, the highest values were recorded for these parameters in plots treated with the organomineral fertilizer compared with NPK treatments. This could be due to enhancement of decomposition of the organic material and mineralization of nutrients especially $\mathrm{N}$ and $\mathrm{P}$ by the presence of mineral fertilizer in the organomineral formulation. Makinde et al. (2010) observed similar increase in growth parameters of Amaranthus cruentus when both kola pod husk and city refuse plus cow dung were fortified with NPK fertilizer, and Ayeni et al. (2008) in a related experiment detected similar increase in $\mathrm{N}$ and $\mathrm{P}$ when cocoa pod ash and poultry manure were respectively fortified with NPK fertilizer. The NSBF engendered significant influences on the vegetable starting from the 3 rd week after planting. This early influence is an indication that a good percentage of the organomineral formulation was mineralized during the 12 weeks of maize growth on the field, and are available for plant uptake. Agbenin et al. (1999) has earlier reported that $\mathrm{N}$ mineralization from neem seed cake (NSC) was fast because between 31 to $35 \%$ of $\mathrm{N}$ was mineralized within eight weeks of incorporation into the soil.

The organic fraction of the organomineral formulation also presumably conferred on it the ability to release its nutrients in installments, with appreciable residual effects on the vegetable grown to succeed maize in rotation (Table 2 to 5 ). It has been reported that only one-fifth to half of the nutrient supplied by organic manure are recovered by the first crops following application. Much of the remaining is held in humus-like compounds subject to very slow decomposition. In this form, the elements are released very slowly, rates of $2.4 \%$ per annum being common (Brady and Weil, 2008). The NSBF increased the growth and yield parameters of Basela alba with increasing rates of application. Regressing growth parameters (Y) against increasing rates of the manures show positive relationships with prediction equations shown in Table 6 . This is probably because higher rates of the fertilizer indicate higher amount of nutrients to be carried over to support the next crop in rotation.

Table 2. Residual effects of neem seed-based fertilizer and NPK on plant height (cm) of Basella alba.

\begin{tabular}{lcccccccc}
\hline \multirow{2}{*}{ Treatment } & \multicolumn{7}{c}{ Weeks after planting } \\
\cline { 2 - 9 } & $\mathbf{3}$ & $\mathbf{4}$ & $\mathbf{5}$ & $\mathbf{6}$ & $\mathbf{7}$ & $\mathbf{8}$ & $\mathbf{9}$ & $\mathbf{1 0}$ \\
\hline NF & $11.83 \mathrm{~b}$ & $17.57 \mathrm{a}$ & $23.73 \mathrm{c}$ & $32.73 \mathrm{c}$ & $53.30 \mathrm{c}$ & $92.57 \mathrm{~b}$ & $116.73 \mathrm{c}$ & $139.40 \mathrm{c}$ \\
$\mathrm{N} 100$ & $12.50 \mathrm{ab}$ & $20.73 \mathrm{a}$ & $27.90 \mathrm{bc}$ & $41.23 \mathrm{bc}$ & $79.27 \mathrm{~b}$ & $107.17 \mathrm{~b}$ & $149.93 \mathrm{bc}$ & $186.77 \mathrm{~b}$ \\
N200 & $9.13 \mathrm{c}$ & $12.07 \mathrm{~b}$ & $26.13 \mathrm{bc}$ & $45.37 \mathrm{~b}$ & $87.80 \mathrm{~b}$ & $108.80 \mathrm{~b}$ & $200.47 \mathrm{a}$ & $233.10 \mathrm{a}$ \\
N300 & $14.57 \mathrm{a}$ & $20.63 \mathrm{a}$ & $30.30 \mathrm{~b}$ & $43.93 \mathrm{~b}$ & $71.97 \mathrm{~b}$ & $162.20 \mathrm{a}$ & $210.80 \mathrm{a}$ & $263.70 \mathrm{a}$ \\
NPK & $8.80 \mathrm{c}$ & $20.55 \mathrm{a}$ & $44.75 \mathrm{a}$ & $67.55 \mathrm{a}$ & $118.85 \mathrm{a}$ & $139.23 \mathrm{a}$ & $151.13 \mathrm{~b}$ & $177.33 \mathrm{bc}$ \\
\hline
\end{tabular}

Means with the same letter in same column are not significantly different from one another. 
Table 3. Residual effects of neem seed-based fertilizer and NPK on number of leaves of Basella alba.

\begin{tabular}{lccccccccc}
\hline \multirow{2}{*}{ Treatment } & \multicolumn{10}{c}{ Weeks after planting } & \multicolumn{10}{c}{} \\
\cline { 2 - 10 } & $\mathbf{3}$ & $\mathbf{4}$ & $\mathbf{5}$ & $\mathbf{6}$ & $\mathbf{7}$ & $\mathbf{8}$ & $\mathbf{9}$ & $\mathbf{1 0}$ & $\begin{array}{c}\text { Leaf area } \\
\left(\mathbf{c m}^{2}\right)\end{array}$ \\
\hline $\mathrm{NF}$ & $6.67 \mathrm{a}$ & $8.00 \mathrm{~b}$ & $9.67 \mathrm{~b}$ & $12.33 \mathrm{~b}$ & $14.67 \mathrm{c}$ & $19.67 \mathrm{~d}$ & $24.67 \mathrm{c}$ & $29.33 \mathrm{c}$ & $49.00 \mathrm{c}$ \\
$\mathrm{N} 100$ & $7.33 \mathrm{a}$ & $9.00 \mathrm{ab}$ & $10.67 \mathrm{~b}$ & $14.00 \mathrm{~b}$ & $19.67 \mathrm{~b}$ & $22.67 \mathrm{~cd}$ & $32.67 \mathrm{~b}$ & $42.00 \mathrm{~b}$ & $60.67 \mathrm{abc}$ \\
$\mathrm{N} 200$ & $7.67 \mathrm{a}$ & $9.00 \mathrm{ab}$ & $11.00 \mathrm{~b}$ & $14.33 \mathrm{~b}$ & $18.00 \mathrm{bc}$ & $26.67 \mathrm{bc}$ & $35.00 \mathrm{~b}$ & $44.67 \mathrm{~b}$ & $61.33 \mathrm{ab}$ \\
$\mathrm{N} 300$ & $7.67 \mathrm{a}$ & $8.00 \mathrm{~b}$ & $9.67 \mathrm{~b}$ & $13.67 \mathrm{~b}$ & $19.00 \mathrm{~b}$ & $34.00 \mathrm{a}$ & $47.50 \mathrm{a}$ & $57.00 \mathrm{a}$ & $69.33 \mathrm{a}$ \\
$\mathrm{NPK}$ & $7.50 \mathrm{a}$ & $10.50 \mathrm{a}$ & $14.50 \mathrm{a}$ & $20.00 \mathrm{a}$ & $25.50 \mathrm{a}$ & $28.67 \mathrm{ab}$ & $33.67 \mathrm{~b}$ & $39.67 \mathrm{~b}$ & $54.00 \mathrm{bc}$ \\
\hline
\end{tabular}

Means with the same letter in same column are not significantly different from one another.

Table 4. Residual effects of neem seed-based fertilizer and NPK on stem girth (cm) of Basella alba.

\begin{tabular}{lccccccc}
\hline \multirow{2}{*}{ Treatment } & \multicolumn{7}{c}{ Weeks after planting } \\
\cline { 2 - 8 } & $\mathbf{4}$ & $\mathbf{5}$ & $\mathbf{6}$ & $\mathbf{7}$ & $\mathbf{8}$ & $\mathbf{9}$ & $\mathbf{1 0}$ \\
\hline NF & $3.50 \mathrm{a}$ & $3.63 \mathrm{a}$ & $3.67 \mathrm{a}$ & $3.77 \mathrm{a}$ & $3.80 \mathrm{a}$ & $3.89 \mathrm{a}$ & $4.00 \mathrm{a}$ \\
N100 & $3.67 \mathrm{a}$ & $3.70 \mathrm{a}$ & $3.80 \mathrm{a}$ & $3.83 \mathrm{a}$ & $3.87 \mathrm{a}$ & $3.93 \mathrm{a}$ & $4.03 \mathrm{a}$ \\
N200 & $3.44 \mathrm{a}$ & $3.47 \mathrm{a}$ & $3.63 \mathrm{a}$ & $3.69 \mathrm{a}$ & $3.70 \mathrm{a}$ & $3.83 \mathrm{a}$ & $3.90 \mathrm{a}$ \\
N300 & $3.57 \mathrm{a}$ & $3.80 \mathrm{a}$ & $3.84 \mathrm{a}$ & $4.90 \mathrm{a}$ & $4.00 \mathrm{a}$ & $4.05 \mathrm{a}$ & $4.45 \mathrm{a}$ \\
NPK & $3.35 \mathrm{a}$ & $3.70 \mathrm{a}$ & $3.80 \mathrm{a}$ & $3.83 \mathrm{a}$ & $3.90 \mathrm{a}$ & $3.95 \mathrm{a}$ & $4.20 \mathrm{a}$ \\
\hline
\end{tabular}

Means with the same letter in same column are not significantly different from one another.

Table 5. Residual effects of neem seed-based fertilizer and NPK on yield parameters of Basella alba plant.

\begin{tabular}{|c|c|c|c|}
\hline Treatment & $\begin{array}{c}\text { Edible yield } \\
\left(\mathrm{g} / \mathrm{m}^{2}\right)\end{array}$ & $\begin{array}{c}\text { Marketable yield } \\
\left(\mathrm{g} / \mathrm{m}^{2}\right)\end{array}$ & $\begin{array}{c}\text { Total biomass } \\
\left(\mathrm{g} / \mathrm{m}^{2}\right)\end{array}$ \\
\hline $\mathrm{NF}$ & $44.00 \mathrm{~d}$ & $114.67 \mathrm{c}$ & $119.33 c$ \\
\hline N100 & $46.33 \mathrm{~cd}$ & $117.00 \mathrm{c}$ & $122.33 c$ \\
\hline N200 & $68.67 b$ & $169.67 \mathrm{~b}$ & $175.33 b$ \\
\hline N300 & $86.50 \mathrm{a}$ & $209.50 \mathrm{a}$ & $217.00 \mathrm{a}$ \\
\hline NPK & $58.67 \mathrm{bc}$ & $153.67 \mathrm{~b}$ & $158.67 \mathrm{~b}$ \\
\hline
\end{tabular}

Means with the same letter in same column are not significantly different from one another.

The effects of the various fertilizer treatments on the yield of Basella alba followed the same trend as the growth parameters. The regression of the various yield attributing parameters against the rates of NSBF (Table 6) indicates a perfect positive correlation. Organomineral fertilizer was found to perform better than NPK irrespective of the rate of application. This supports the works of many authors who have discovered the merits of combining organic and mineral fertilizers
- as organomineral fertilizers. Kang and Balasubramanian (1990) and Babatola et al. (2002) recorded high yields of leafy vegetables following the application of organomineral fertilizers and suggested that high and sustained yield could be obtained with judicious and balanced NPK fertilizer combined with organic source of plant nutrients. Ipinmoroti et al. (2002) in their experiment indicated that quick mineralization of inorganic component and the slow nutrient release of the organic constituents of 
organominerals must have sustained the continous better performance of A. cruentus than their separate applications. Results of the effect of the different retaes of NSBF on the proximate composition of Basella alba is presented in Table 6. The fertilizers tested irrespective of type or application rate did not significantly affect moisture content of Basella alba (Table 7). NSBF at the highest rate $(200 \mathrm{~kg} / \mathrm{ha})$ however recorded the lowest moisture content. This may indicate that NSBF engendered better dry matter accumulation in the vegetable (Table 8). This rate also caused significantly higher crude protein accumulation in the plants, which is an indication of higher $\mathrm{N}$ uptake and better $\mathrm{N}$ use efficiency.

Table 6. Linear correlation and regression analysis between increasing rates of NSBF $(X)$ and growth or yield parameters of Basella alba $(\mathrm{Y})(\mathrm{n}=3)$.

\begin{tabular}{lcc}
\hline Parameter & Correlation coefficient & Regression equation \\
\hline Plant height & +0.99 & $\mathrm{y}=112.5+0.77 \mathrm{x}$ \\
Leaf number & +0.94 & $\mathrm{Y}=25.4+0.15 \mathrm{x}$ \\
Leaf area & +0.89 & $\mathrm{Y}=50.8+0.09 \mathrm{x}$ \\
Stem girth & +0.73 & $\mathrm{Y}=3.5+0.01 \mathrm{x}$ \\
Edible yield & +0.99 & $\mathrm{Y}=6.9+0.40 \mathrm{x}$ \\
Marketable yield & +0.99 & $\mathrm{Y}=26.6+0.93 \mathrm{x}$ \\
Total biomass & +0.99 & $\mathrm{y}=29.5+0.95 \mathrm{x}$ \\
\hline
\end{tabular}

Table 7. Residual effects of neem seed-based fertilizer and NPK on leaf proximate composition of Basella alba plant.

\begin{tabular}{lcccc}
\hline Treatment & $\begin{array}{c}\text { Moisture content } \\
(\mathbf{\% )}\end{array}$ & $\begin{array}{c}\text { Ash } \\
\mathbf{( \% )}\end{array}$ & $\begin{array}{c}\text { Protein } \\
\mathbf{( \% )}\end{array}$ & $\begin{array}{c}\text { Fat } \\
\mathbf{( \% )}\end{array}$ \\
\hline NF & $18.16 \mathrm{a}$ & $13.21 \mathrm{a}$ & $6.52 \mathrm{~d}$ & $3.70 \mathrm{~cd}$ \\
N100 & $18.97 \mathrm{a}$ & $5.77 \mathrm{c}$ & $12.62 \mathrm{bc}$ & $2.86 \mathrm{~d}$ \\
N200 & $18.88 \mathrm{a}$ & $7.69 \mathrm{~b}$ & $15.23 \mathrm{~b}$ & $4.90 \mathrm{~b}$ \\
N300 & $15.89 \mathrm{a}$ & $7.84 \mathrm{~b}$ & $19.52 \mathrm{a}$ & $7.77 \mathrm{a}$ \\
NPK & $17.30 \mathrm{a}$ & $7.84 \mathrm{~b}$ & $12.11 \mathrm{c}$ & $3.92 \mathrm{c}$ \\
\hline
\end{tabular}

Means with the same letter in same column are not significantly different from one another.

Table 8. Residual effects of neem seed-based fertilizer and NPK on leaf nutrient composition of Basella alba plant.

\begin{tabular}{lcccc}
\hline Treatment & $\begin{array}{c}\text { Nitrogen } \\
\mathbf{( \% )}\end{array}$ & Phosphorus & Potassium & Vitamin C \\
\hline NF & $1.04 \mathrm{~d}$ & $10.43 \mathrm{~b}$ & $23.21 \mathrm{ab}$ & $9.28 \mathrm{c}$ \\
N100 & $2.02 \mathrm{bc}$ & $9.72 \mathrm{~b}$ & $19.61 \mathrm{bc}$ & $9.28 \mathrm{c}$ \\
N200 & $2.44 \mathrm{~b}$ & $10.94 \mathrm{~b}$ & $16.92 \mathrm{c}$ & $13.92 \mathrm{~b}$ \\
N300 & $3.12 \mathrm{a}$ & $13.66 \mathrm{a}$ & $25.39 \mathrm{a}$ & $18.56 \mathrm{a}$ \\
NPK & $1.94 \mathrm{c}$ & $10.63 \mathrm{~b}$ & $17.06 \mathrm{c}$ & $9.28 \mathrm{c}$ \\
\hline
\end{tabular}

Means with the same letter in same column are not significantly different from one another. 


\section{Conclusions}

Excellent growth and yield of Basella alba were obtained with the higher rates of the neem seed-based fertilizer. This is an indication that the organomineral formulation possesses good nutrient carry-over effects and can be recommended for use in a sustainable integrated soil nutrient management programme.

\section{Conflicts of interest}

Authors declare that they have no conflict of interests.

\section{References}

Adeniyan, O. N.; Ojeniyi, S. O. Effect of poultry manure, NPK 15-15-15 and combination of their reduced levels on maize growth and soil chemical properties. Nigerian Journal of Soil Science, v. 15, p. 34-41, 2005.

Adeoluwa, 0. 0.; Adeogun, 0. O. Evaluation of feather as organic fertilizers on amaranthus (Amaranthus caudatus). Proceedings of 1st Technical Workshop on Organic Agriculture Conference, Ladoke Akintola University of Technology, Ogbomoso, p. 16-19, 2010.

Adeoye, G. O.; Sridhar, M. K. C.; Adeoluwa, O. O.; Oyekunle, M.; Makinde, E. A.; Olowoake, A. A. Comparative evaluation of organo-mineral fertilizer (OMF) and mineral fertilizer (NPK) on yield and quality of maize (Zea mays (L) Moench). Nigerian Journal of Soil Science, 18, p. 141-147, 2008.

Agbenin, J. O.; Agbaji, E. O.; Suleiman, I.; Agbaji, A. S. Assessment of nitrogen mineralization potential and availability for neem seed residue in a Savanna soil. Biology and Fertility of Soils, v. 29, p. 408-412, 1999.

Akinrinade, E. A.; Obigbesan, G. O. Evaluation of the fertility status of selected soils for crop production in five ecological zones of Nigeria. Proceedings 25th Annual Conference of Soil Science Society of Nigeria, Ibadan, p. 279$288,2000$.
AOAC - Association of Official Analytical Chemist. Official method of analysis. Rockville: AOAC, 1995.

Ayeni, L. S. Integration of cocoa pod ash, poultry manure and NPK 20:10:10 fertilizer for soil fertility management: Incubation study. Continental Journal of Agronomy, v. 2, p. 25-30, 2008.

Babatola, L. A.; Adebayo, O. B.; Lawal, O. I. Effects of different rates of poultry manure and NPK on performance of Celosia argentia. Proceeding of Horticultural Society of Nigeria, Ibadan, p. 54-56, 2002.

Brady, N. C.; Weil, R. R. The nature and properties of soils. 12. ed. New Jersey: Prentice Hall, 2008.

Fagbola, O.; Ogungbe, P. N. Growth and yield response of some maize cultivars to organomineral fertilizer application in simulated degraded soil under greenhouse condition. Nigerian Journal of Soil Science, v. 7, p. 87-93, 2007.

FAO - Food and Agriculture Organization. Agricultural production: Primary crops. Rome: FAO, 2003.

Gordon, W. B.; Whitney, D. A.; Raney, R. J. Nitrogen management in furrow irrigated, ridge tilled corn. Journal of Production Agriculture, v. 6, p. 213-217, 1993.

Ipinmoroti, R. R.; Adeoye, G. C. Effect of organic and NPK fertilizers on tea (Camellia sinesis) performance on a humid lowland ecological area of South Western Nigeria. Proceedings of Horticultural society of Nigeria Conference, Ibadan, Nigeria, p. 69-74, 2002.

Kang, B. T.; Balasubramaniam, V. Long term fertilizer trial on Alfisols in West Africa. Transactions of XIV International Soil science Society (ISSS) Congress, Kyoto Japan, 1990.

Makinde, E. A.; Ayeni, L. S.; Ojeniyi, S. O. Morphological characteristics of Amaranthus cruentus L. as influenced by Kola Pod Husk, organomineral and NPK fertilizers in Southwestern Nigeria. New York Science Journal, v. 3, no. 5, p. 130-134, 2010. 
Ojeniyi, S. O.; Ezekiel, P. O.; Asawalam, D. O.; Awo, A. O.; Odedina, S. A.; Odedina, J. N. Root growth and NPK status of cassava as influences by oil palm bunch ash. African Journal of Biotechnology, v. 18, p. 44074412, 2009. original work is properly cited. 